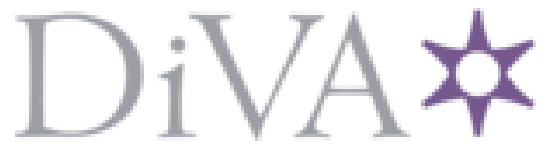

http://www.diva-portal.org

\title{
Postprint
}

This is the accepted version of a paper published in Central Asian Survey. This paper has been peer-reviewed but does not include the final publisher proof-corrections or journal pagination.

Citation for the original published paper (version of record):

Matthew, B. (2019)

Discourses of Russian-speaking youth in Nazarbayev's Kazakhstan

Central Asian Survey

https://doi.org/10.1080/02634937.2019.1615409

Access to the published version may require subscription.

N.B. When citing this work, cite the original published paper.

Permanent link to this version:

http://urn.kb.se/resolve?urn=urn:nbn:se:uu:diva-385767 


\section{Discourses of Russian-speaking youth in Nazarbayev's Kazakhstan: Soviet Legacies and responses to nation-} building

Abstract

Research into post-independence identity shifts among Kazakhstan's Russian-speaking minorities has outlined a number of possible pathways, such as diasporization, integrated national minority status and ethnic separatism. Drawing on semi-structured interviews with young people in Almaty and Karaganda, I examine how Russian-speaking minorities identify with the state and imagine their place in a 'soft' or 'hybrid' post-Soviet authoritarian system. What is found is that Russian-speaking minorities largely accept their status beneath the Kazakh 'elder brother' and do not wish to identify as a 'national minority'. Furthermore, they affirm passive loyalty to the political status quo while remaining disinterested in political representation. Russian-speaking minorities are also ambivalent toward Kazakh language promotion and anxious about the increasing presence of Kazakhspeakers in urban spaces. This paper argues two factors are central to these stances among Kazakhstan's Russian-speaking minorities: the persistence of Soviet legacies and the effects of state discourse and policy since 1991.

\section{Introduction}

With the fourth largest Russian-speaking population in the world ${ }^{1}$, Kazakhstan remains an important case study in the identity trajectories of Russian-speaking minorities in the post-Soviet space. ${ }^{2}$ Given Kazakhstan's strategic location, an apparent dependence on Moscow and the increased assertiveness of Russia in the Post-Soviet space, the group identification trends of Russian-speaking minorities has potentially serious ramifications domestically and internationally. On the other hand, demographic decline among Russian-speaking minorities raises the prospect of a more monoethnic, Kazakh-speaking country, reducing the salience of the 'Russian question' ${ }^{3}$ At the current moment, however, this is not the case; a delicate balance remains in Kazakhstani society between Russian-speaking and Kazakh-speaking components. The final years of Nursultan Nazarbayev's presidency were marked by a certain hesitation and uncertainty in nation-building policy initiatives. ${ }^{4}$ The departure of this markedly Russophone leader will surely have a bearing on the future role of non-titular Russian-speaking citizens. Their continued presence,

\footnotetext{
1 The ethnic Russian population was estimated at 3,793,764 in 2009 during the last official population census (the next is planned for 2019). The numbers from stat.gov.kz for 2018 show this has declined to $3,588,686$.

2 By 'Russian-speaking minorities' I mean non-titular Russian-speaking (russkoyazichnie) citizens of Kazakhstan whose first language and primary cultural identification is Russian. This avoids using 'Russian' (russkii), which has much historical and contemporary ambiguity. It also does not break the population up into ethnic sub-groups (such as 'Ukrainians', 'Russians', 'Jews') in a deterministic and primordialist fashion. Respondents in this study all self-identified as 'Russian' (russkii) or 'Russian-speaking' (russkoyazichnie) and did not claim 'Kazakh' identity. ${ }^{3}$ Russian-speakers are trickling out of the country at the rate of a medium-sized town each year. In 2014 around 28,900 emigrated, in 2015 another 30,000 left (Karavan 2016). As for demographic trends, ethnic Kazakh population growth in 2015 was 2.3 percent while the Russian population was shrinking at a rate of 0.51. In terms of average age, in 2013 this was 28.9 for Kazakhs, 38.5 for Russians and 43 for Ukrainians (Laruelle 2016: 71).

${ }^{4}$ Consider the stop-start process of promoting Kazakh as the state language, aborted moves to change the name of the country from Kazakhstan to the Kazak Yeli (Kazak Yeli translates roughly as 'Kazakh Country' http://www.eurasianet.org/node/68017) or delays to the long anticipated shift from Cyrillic to Latin script, which has now been postponed till 2025 (https://astanatimes.com/2017/10/kazakhstan-to-switch-to-latinalphabet-by-2025/
} 
integration and assimilation (as opposed to increasing alienation and emigration from the country) is of considerable importance to regime stability and regional interstate dynamics.

This paper examines identity discourses among younger members of Kazakhstan's Russian-speaking minorities aged 18-30, revealing the 'common-sense ways' respondents 'carve up the social world' (Brubaker 2004, p.9). In contrast with the 'top-down' approaches common to a substantial part of the literature (Kolstø 1999, Schatz 2000, Dave 2007, Ó Beacháin and Kevlihan 2013, Laruelle 2015), I follow what others have called a 'citizen-focused approach' (Rees, Webb Williams 2017, Isaacs, Polese 2015) to uncover attitudes towards the Kazakhstani state and society 'from below'. In taking this approach, I highlight how Russian-speaking minorities construct the existing social and political institutions of 'state' and 'nation' through everyday contact with other groups, in particular ethnic Kazakhs. Revealing these discourses locates identification and belonging, as well as fears and hopes, on the micro level, shedding light on what minorities experience and how they perceive of the possibilities open to them in contemporary Kazakhstan.

This paper interprets the narratives of the Russian-speaking minority with reference to two important contextual factors. The first is the continued strength of ways of thinking and acting common to a Soviet-Russian identity. Indeed, this paper argues that Soviet legacies work against increased identification as a 'diaspora' or 'national minority’ among Russian-speakers. This dynamic can be observed in attitudes to history and language, where a 'cultural colonialism' is reproduced, as well as in politically disengaged stances and pessimism about initiating bottom-up change. Secondly, interview narratives also reflect responses to nation-building policies in post-Soviet Kazakhstan, where Soviet-style discourses on the nation are actively promoted and political opposition groups, especially those representing the putative Russian-speaking community, have been squeezed out of the public domain. These policies appear to reinforce Soviet-Russian attitudes and stances, resulting in the apparent inactivity or passivity of Russian-speaking minorities. It is this very inertness that can raise the question whether Russianspeakers deserve to be studied as a group. I will address such doubts in the next section before moving to the main body of the paper.

\section{The Case for Studying 'Russian-speaking minorities' as a Group}

One of the difficulties in studying 'Russian-speaking minorities' in Kazakhstan is the lack of clearly demarcated or visible group activity among 'Russian-speakers'. ${ }^{5}$ While state discourse in Kazakhstan refers to the vital role of the

\footnotetext{
${ }^{5}$ This is in stark contrast to other former Soviet republics such as Latvia, where an influential discourse emerged on Russian-speakers as a
} minority and political parties have emerged to represent them and play a central role in politics (Cheskin 2013; Kosmarskaya 2014). 
titular nation (ethnic Kazakhs) and celebrates internationalism and the diverse national minorities in the republic (each conceived of as a distinct ethnic unit, e.g. Tatars, Ukrainians, etc.), the category of Russian-speaking (russkoyazichnie) citizens is avoided by the authorities. Instead, a deproblemitised picture is presented of all citizens speaking Kazakh, Russian and English in a near, trilingual, future. ${ }^{6}$ The Russian Federation, as well as Russian media outlets in Kazakhstan, have also proven reluctant to point towards the 'rights' or 'interests' of a Russians or the Russian-speaking community (Laruelle 2016, p 67, 73). While political 'entrepreneurs' have encouraged a sense of 'Kazakhness' in the titular nation, there is less clear evidence of any parallel activity being conducted among Russian-speaking minorities. With this point in mind, this study did not include Russian-speaking Kazakhs as part of the 'Russian-speaking minorities'; the complexity of the titular nationality's linguistic and cultural divisions are worthy of a separate study

Indeed, one might conclude that, deprived of identity entrepreneurs from the 'kin' and 'host' state, and lacking the attention of significant international or domestic organisations, the prospects for the maintenance of a viable group identity among Russian-speaking minorities is limited. I would argue, however, there are two good reasons to retain the category of 'Russian-speaking minorities' and 'Russian-speaking communities'. Firstly, there are the shared historical experiences, cultural-linguistic homogeneity and socialisation emerging from long-term Sovietisation. The Russian-speaking minority population of today's Kazakhstan is the product of the voluntary and forced settlement of a variety of ethnic groups over an extended period of time (Kosmarskaya 2006, pp.190-198). In the Soviet period, these Russian-speaking minorities tended to identify as 'Russian' (russkii), a category not based on ethnicity or blood but more connected to membership of a cultural and socio-economic group leading a civilizational/modernisation project in an 'undeveloped' periphery (Central Asia) (Melvin 1998; Hosking 2006). ${ }^{7}$ Participants in this project all defined themselves as Russian (russkii) even though around half of them reported mixed ethnicity. ${ }^{8}$ As one respondent put it, 'being Russian (russkii) is not an ethnic thing but a condition of the soul' (Ruslan, 22, Karaganda).

The second reason to study Russian-speaking minorities as a group is the argument that they form one pole in Kazakhstan's 'bipolar society’. This cultural and linguistic bipolarity emerged historically when Russian-speaking settlers and Russified ethnic Kazakhs migrated into newly built towns, while the Kazakh-speaking pastoral nomads

${ }^{6}$ The Kazakhstani authorities claim increasing proficiency in the state language (Kazakh), with bold promises that 'by 2025 , $95 \%$ of Kazakhstanis' will be fluent in Kazakh (Nazarbayev 2012). The same document (Kazakhstan 2050) also promises the status of Russian will be preserved, while a 'breakthrough' (rivok) in English fluency levels will also be achieved, thus bringing about a trilingual Kazakhstan. https://en.tengrinews.kz/edu/Nazarbayev-calls-Kazakhstan-to-learn-English-24393/ In his recent resignation speech, Nazarbayev made additional reference to this vision of a future society of 'educated, free people, speaking in three languages'. (Nazarbayev 2019)

${ }^{7}$ Soviet-Russians enjoyed 'public status, linguistic privilege and cultural facilities' and typically viewed the whole of the USSR as their homeland, rather than one of the republics (Brubaker 1994, p 68). This identity was reinforced by the dominance of Russian as language of interethnic communication and the mass dissemination of a Sovietised Russian culture throughout the country (Hosking 2006).

${ }^{8}$ The full range of these was: Russian/German, Russian/Ukrainian, Tartar/Russian, Belarusian/Jewish, Russian/Ukrainian, Russian-Polish, Russian-Korean and Russian-Kazakh. 
remained on the steppe or, later, were forced into collective farms (Kolstø 1999, p. 45). Some authors have argued this continues into the present day, with a 'European' pole, which is predominantly urban, secular multi-ethnic and Russian-speaking, contrasted to an 'Asian' pole, largely made up of a more monoethnic Kazakh-speaking population with roots in the countryside, many of whom adhere to more 'traditional' values (Kolstø 1999; Laitin 1998; Brubaker 2011). After the demographic shifts of the 1990's, it is hard to ascertain whether nation-building policies and economic growth have reduced this bipolarity in Kazakhstani society. While the census of 2009 shows Russian-speaking minorities are not shifting toward Kazakh language and culture, the actual preferences and practices of 'Russified' urban Kazakh families are not clear (Astana 2009). ${ }^{9}$ Making up 27\% of the population ${ }^{10}$ (to which can be added an unknown number of Russified Kazakhs), the Russian-speaking population still accounts for much of the urban, middle-class tier of society (Smagulova 2016, pp.101-103). Thus, given the common 'SovietRussian' socialization, the relative cultural and linguistic unity regardless of actual ethnicity, as well as the niche role in the urban centres, it is possible to justify studying Russian-speakers as a group in the Kazakhstan context.

\section{Research Methodology}

In order to explore how younger Russian-speakers conceived of state, belonging and society, one-to-one semistructured interviews were conducted in Almaty (15) and Karaganda (10). The interviews explored family biographies, the history of Russian-speakers in the country, everyday life as Russian-speakers, attitudes to state policies and perceptions of Kazakhstan and Russia. Benefiting from one full year to live, work and study in Kazakhstan, I was able to employ snowball sampling to build a pool of respondents in Almaty and Karaganda from the ages of $18-30 .{ }^{11}$ Due to time and resource limitations, I was unable to interview respondents in the more 'Russian' regions of the country in the North (Kostanay, Petropavl) and East (Pavlodar, Ust'-Kamenogorsk). It is likely that these areas of compact settlement would offer contrasting views to that of Almaty and Karaganda, where only one third and one quarter of the population are Russian respectively (Laruelle 2016, p.68). On the other hand, the cities chosen in this research are useful as sites of contact between various groups: Russian-speaking minorities, Russian-speaking Kazakhs and, often newly arrived from the countryside, Kazakh-speakers.

\footnotetext{
9 There is a lack of reliable statistical data that could verify actual language proficiency, preferences and usage among the titular nation. Juldyz Smagulova (2008, p.470) pointed out state population censuses claiming 95\% fluency among ethnic Kazakhs in Kazakh language hides 'the intricate nature of language proficiency by approaching it as a monolithic phenomenon'. According to her surveys, the preference for Kazakhlanguage usage and education is higher among younger, poorer and more rural ethnic Kazakhs. Thus, 'Kazakh is more likely to be used by those who spend less' while Russian remains 'the dominant language of communication across all domains' as well as 'the language of a more powerful social group - affluent urban residents' (ibid, pp.462-466).

${ }^{10}$ Adding together Ukrainians $(277,514)$, Belarussians $(55,943)$, Tatars $(202,121)$, Germans $(179,476)$ and Russians $(3,588,686)$ brings the 'Russian-speaking minorities' population to 4.3 million ( $27 \%$ of population) as opposed to 12.1 million ethnic Kazakhs (67\% of population) (stat.gov.kz)

11 The ratio of male to female respondents was $1: 1$, and the professions included engineers, IT specialists, students of various subjects, accountants and those working in media. This data set focuses more on an urban, somewhat privileged stratum, who have not begun or are in the early stage of their careers. All the respondents were from urban backgrounds and had some level of higher education.
} 
Other limitations to the data pool must also be highlighted. I was unable to interview representatives of the working classes and those without higher education, as my snowball sampling did produce referrals to this part of the community. As my sample leans more to the middle-class segment of Russian-speaking minorities, the picture that emerges here may contrast with that of working-class youth in other parts of Kazakhstan (Kesküla 2018) or those of smaller or rural population centres. Almaty continues to be a vital generator of wealth in the economy as a whole ( 8 billion Tenge RGP in 2014), while Karaganda produces a more moderate amount (three billion Tenge in the same year) (ibid, p.72). Both data collection sites are zones of economic opportunity relative to the overall condition of the country. Almaty still offers upward social mobility for Russian-speaking minorities while Karaganda retains certain key industries and a long history of Russian-speaking minorities (consider the predominance of coal-mining, the settlement of ethnic Germans and the presence of KarLag). Thus, the findings of this study may not reflect the overall situation for Russian-speakers in Kazakhstan, which would require a far more extensive sampling process. While the conclusions of this paper cannot be generalised to the whole of Kazakhstan, they do shed light on the key parameters of discourse and offer ideas for future research into Russian-speaking minorities in the Post-Soviet space.

\section{Interpreting 'Soviet legacies'}

Much of the early research on Russian-speakers in Kazakhstan was dominated by the research paradigm of 'transition', where the assumption was that the Soviet legacies of 'colonialism' and 'authoritarianism' could be shed like so much dead weight (Ekiert 2015, p.329). Research into the Russian-speaking minorities of the newly independent states examined the possibilities of diaspora formation (King and Melvin 2000; Laitin 1998) and, influenced by Rogers Brubaker's 'Triadic Nexus' (1995), considered the effects of the 'nationalising state' (Cummings 2005; Dave 2007). It soon became clear that Russian-speaking minorities took relatively positive or neutral stances toward the 'nationalising state' in Kazakhstan (Barrington et al 2003; Peyrouse 2007; Dave 2007) and did not identify or behave as a 'diaspora'12 nor a 'national minority' (Barrington et al 2003, Kosmarskaya 2011).

It appears cultural codes, institutional behaviour and political and social traditions from the Soviet period have proven more influential and lasting than expected (Ekiert 2015; Kotkin and Bessinger 2014). By 'legacies', I mean how the beliefs, practices and ideas of one period endure to influence and shape developments in the present (Kotkin and Bessinger 2014, p.7). Of the four types of 'legacy relationships' discussed by Kotkin and Bessinger, the most

\footnotetext{
${ }^{12}$ Smith (1999) convincingly rejected the notion of a 'Russian diaspora' as they: (i) lacked a real sense of communal identity or willingness to collective action; (ii) lacked solidarity with other Russians 'stranded' in other countries; (iii) lacked the physical migration needed to constitute diaspora; the USSR may have collapsed but they themselves did not actually move. Cohen (2008: 79) has referred to them as a 'stranded minority' rather than a displaced population.
} 
pertinent to this research was 'cultural schemata': 'embedded ways of thinking and behaving that originate from socialization experiences under the prior political order' that 'persist long beyond the macropolitical rupture' (ibid, p.15). The framework of 'cultural schemata' overlaps with Pierre Bourdieu's concept of 'habitus' (2002, pp.27-28): inbuilt and often subconscious 'manners of being, seeing, acting and thinking' that shape how people interpret reality. ${ }^{13}$

Two key elements of the Soviet legacy are worth underlining for Russian-speakers in Kazakhstan: the continued influence of the Soviet-Russian identity and the special nature of Soviet 'imperialism' and 'colonialism'. Firstly, sociological research into Soviet-Russian identity (Levada et al 1993) revealed limited identification with any ethnic group and more feelings of belonging to the malaya rodina ${ }^{14}$ and the Soviet Union as a whole (Arutyunyan, Drobizheva 1987; Kaiser 1994). In addition, paternalistic views of the state prevailed, as well as a preference for hierarchy and surprisingly low levels of collectivism. Much of this can be explained by the habits the Soviet people adopted over generations of authoritarianism: loyalty to the authorities became largely symbolic, the private sphere of family was prioritised, while, on the whole, very few demands were made of the authorities. ${ }^{15}$ As will be seen below, aspects of this Soviet-Russian habitus resonate in the stances and imaginaries of the participants in this research, despite the fact that they have grown up in Post-Soviet settings.

Another important component of the Soviet legacy concerns the breakup of the USSR into independent nationstates. To some 'decolonisation' entailed loss of status as a 'dominant group' for the Russian-speaking minorities of the newly independent states (Stasiulis, Yuval-Davis, 1995, p.2). Here one should be careful about viewing the USSR through a post-colonial lens as a classic empire along the lines of the British and the French. The Russianspeakers in Kazakhstan were not agents of capitalist exploitation, nor did they wield political power in a manner similar to colonial elites in other European empires. The kind of 'imperial' identity that emerged in the Soviet Union was tied up with ambitious goals to modernise, develop along socialist lines, while transforming diverse ethnic groups into one 'Soviet people'. ${ }^{16}$ However, as the historian Alexander Morrison (2016) has pointed out, 'becoming "Soviet" in essence meant learning Russian and adopting Russian cultural norms'. Thus, a certain 'cultural

13 As Grzegorz Ekiert noted (2015, p.334), Max Weber provided a famous example of how the habits and behaviour of protestant congregations were central to the emergence of capitalism. These protestant legacies endured beyond their original church community settings to act as a legacy on entrepreneurial activity. Kotkin and Bessinger $(2014$, p.9) point to the example of Alexis de Tocqueville's analysis of the French Revolution, which argued the habits and attitudes of France's absolutist political culture frustrated the revolutionaries' desire to achieve a clean break from feudalism.

${ }^{14}$ This translates as 'little homeland', which could mean village, town or region.

${ }^{15}$ Indeed, these features were described as early as 1985 by the American economist James Millar (1985) as Brezhnev's conservative 'Little Deal', where the Party-state reduced ideological demands considerably, relaxed control of certain spheres and permitted petty corruption in the pursuit of improving one's lot (i.e. acquiring consumer goods and attaining middle-class status). In return, citizens disengaged from politics in return, leaving the Party to look after things.

${ }^{16}$ It can be argued the Soviet authorities used central planning to balance the benefits of modernisation rather evenly across the whole union in ways that were incomparable to classic empires (Chari, Verdery 2009, p.15). On the other hand, the Soviet state was 'imperialist' in the way the Centre used its power against the perhiphery by imposing repressive systems upon 'subject' nations, such. forced industrialisation, collectivization, as well as mass purges and arrests of national intelligentsias. 
colonialism' did exist, and the Soviet 'friendship of nations' concealed certain hierarchies and inequalities. ${ }^{17}$ As will be discussed below, rather than fading away, this 'cultural colonialism' appears to have survived and evolved in the post-Soviet period.

In highlighting these two elements of the Soviet legacy, it is important to note that it is beyond the scope of this paper to explain how these continuities survive, be it through generational transmission, the active work of actors on the ground or the influence of social institutions. As I will argue in the next section, however, the discourses and policies of the Kazakhstani state post-1991 draws on elements of the Soviet political tradition and clearly form an additional contextual factor in Russian-speaking identity.

\section{Kazakhstani Nation-building: Discourses and Policies}

Marlene Laruelle (2015) argues that three 'discursive paradigms of state identity' are vital to nation-building in Kazakhstan. These revolve around the themes of 'Kazakhness, Kazakhstanness and Transnationalism', each of which is also backed by a set of concrete policies. The first, 'Kazakhness', refers to the idea ethnic Kazakhs as the titular and central core group of the country. ${ }^{18}$ This discourse finds practical realisation in policies of ‘Kazakhisation' (Kolstø 1998; Cummings 2005; Olcott 2002; Peyrouse 2008a), underlining the 'Kazakh’ identity of the country by renaming streets, unveiling new symbols rewriting history and ensuring ethnic Kazakh monopolisation of political structures and demographic dominance (Diener 2002, 2005; Oko 2007, pp.82-83; Akiner 2005, p.27). ${ }^{19}$ These policies were combined with repressive measures enacted after the dissolution of the Supreme Soviet in $1995 .^{20}$ Among its targets were organisations such as Lad and Russkaya Obshchina, who claimed to represent the Russian-speaking community. ${ }^{21}$ Legal harassment, street beatings and arrests resulted in the emigration of many activists (Oko 2007, p.123). Bhavna Dave (2004, p97; 2007) convincingly argued that the above policies deprived Russian-speakers of leaders, discouraged them from articulating a voice and led to increased emigration,

\footnotetext{
17 Russians and Russian-speakers (russkoyazichnie) enjoyed special status as the 'elder brothers' and 'vanguard' in the construction of socialism across the Soviet Union. Soviet-Russian identity combined a 'civilizing mission' with a civic nation-building project that sought to merge the various ethnicities of the countries into one 'Soviet people' (sovetskii narod) (Suny 2012, p.24).

${ }^{18}$ This is enshrined in the 1996 'Concept for the Formation of a State Identity of the Republic of Kazakhstan', which argued that as Kazakhs do not possess statehood anywhere else in the world, Kazakhstan is a national, Kazakh state. (Laruelle 2015, p 2).

${ }^{19}$ It should not be assumed these efforts to promote Kazakh national identity were straightforwardly successful; there is evidence clan and kinship subdivisions have been a serious complicating factor (Schatz 2012). Given that the roots of this are a legacy of local responses to Soviet rule, post-Soviet transformations and continuity with practices and ways of thinking dominant in the Soviet period are also a vital part of understanding the evolution of Kazakh identity.

${ }^{20}$ The period 1991-1994 was characterized by the influence of 'liberal' reformers and the passing of a constitution that secured parliamentary powers in the Supreme Soviet. By 1994, Nazarbayev, through various means, secured the dissolution of the Supreme Soviet prior to new elections. When, after the elections, the new parliament resisted Nazarbayev's constitutional amendments in favour of presidential power, the Supreme Soviet was dissolved again in 1995, allowing the president to push through a new constitution and significantly increase his powers (See Cummings 2005, pp.23-29). By the end of the nineties the threshold for participation in elections was increased, the term of the president raised from five to seven and, by 2001, a new law on political parties made registration and participation in elections for non-systemic parties extremely difficult.

21 The pan-Slavic organisation Lad and the Russian Community of Kazakhstan (Russkaya Obshchina) stood out as vigorous defenders of Russian-speakers in the nineties. Fighting on a platform of equal status for Russian language and allowing dual citizenship with Russia, Lad won seats in the Supreme Soviet in 1994 and collected hundreds of thousands of signatures on its petitions. At its peak, Lad had twelve regional offices, 20,000 members and 400 activists (Peyrouse 2007, p.488).
} 
and political disempowerment and disengagement for those left behind. The depoliticised stances revealed below in respondent narratives should be understood with reference to these repressive policies.

The second discursive paradigm reflects state commitment to a multinational (mnogonatsional'naya) Kazakhstan: the idea that all the citizens of Kazakhstan, regardless of ethnicity, share a common homeland and destiny. This contains themes that echo Soviet internationalism: the state trumpets its commitment to interethnic stability and fairness (Schatz 2000, p.491) and Kazakhstan's various ethnic groups are seen to merge in the 'Eurasian' space. ${ }^{22}$ This Soviet-style imagery, updated with the ethnic Kazakhs replacing the Russians as the 'elder brother', emerges as an important theme in respondent narratives. The third discursive frame, 'Transnationalism', which is also referred to as 'modernizing nationalism' (Kudaibergenova 2015), provides an 'overarching agenda for all citizens of Kazakhstan', transcending individual and ethnic group positions on identity (ibid, p.440). As Mateusz Laszczkowski (2016, p.58) also pointed out, this discourse replays 'Soviet, modernist visions of social transformation' and legitimizes the regime through the promise of economic improvement for all. Here, the emphasis is on Kazakhstan's linear progression into the ranks of the developed countries, achieved by leading and hosting international events, diversifying the economy, and investing in sports and education (Laruelle 2015, pp.10-12). The credibility of this discourse is grounded in the economic growth of the 2000's and Kazakhstan's position as second only to Russia among CIS states in terms of economic attractiveness. ${ }^{23}$ Thus, the last two of these discursive paradigms reinforce Soviet legacies in identity and must be considered as a factor in how Russian-speaking minorities negotiate their identity in contemporary Kazakhstan.

\section{Views of the Past: The Persistence of Cultural Colonialism}

In his analysis of Russians as an 'imperial minority' in contemporary Kazakhstan, Peyrouse (2008b, p.109)

highlighted two 'radically conflicting' discourses in Kazakhstan's historiography. Firstly, there is the 'Kazakh nationalist' version which claims Kazakhstan's statehood existed for centuries prior to the being undone by Mongols, Zhungars and, finally, Russians, all of whom sought to annex a chunk of the steppe and exploit the Kazakhs. In contrast, the 'Russian' version emphasises the positive influence of modernization and civilization the Russian-speaking influx brought, as, first Tsarist, then Soviet rule hauled Kazakhstan out of the Middle Ages and created the basis for the independent modern state of today. This version sidesteps any accusation of colonialism or

\footnotetext{
${ }^{22}$ In policy terms, internationalism is reflected in the fact that, after independence, Kazakhstani citizenship was not limited to ethnic or 'native' titulars (as in Estonia and Latvia) (Laitin 1998, p.98). Furthermore, the status of Russian was recognised in constitutional statutes 7.2 and 7.3. Finally, the Assembly of the People of Kazakhstan (ANK) was established), which coordinates nationality policy and supervises the work of around 800 ethnic associations and 170 weekend schools (Laruelle 2015, p 7).

${ }^{23}$ From 2003 to 2008 the country enjoyed an average annual growth of $8.6 \%$ while Gross National Income PPP per capita rose from $\$ 6530$ in 2003 to $\$ 11,950$ in 2012. World Bank statistics available at http://data.worldbank.org/country/kazakhstan. Overall, Russian-speaking minorities have been well positioned to enjoy the fruits of this relative prosperity.
} 
occupation; instead Kazakhstan is presented as a place where many ethnic groups intermingle peacefully and druzhba narodov is taken to have been a genuine reality. There was remarkable consistency across respondent narratives on the history of 'the Russians in Kazakhstan'. The central theme was that Russians and Russianspeakers arrived in a steppe without anything resembling modern 'civilization' and that the Kazakhs 'were used to living with nothing, they had their saddle, horse, tent or yurt and that was it' (Yuri, 22, Karaganda). Additionally, 'Russians did not come as conquerors' but were 'invited by weak Kazakh zhuses under threat of total domination from an other tribal entity' (Julia, 27, Almaty).

While absorption into the Russian Empire was generally portrayed as 'voluntary' and 'harmonious', the harsher policies of the Soviet period were often acknowledged. It was common for this 'harshness' to be understood in terms of repression, forced settlement and cultural destruction. The Soviets 'came and forced Kazakhs off their saddle and into work' and 'took resources out of Kazakhstan'(Ruslan, 22, Karaganda). They also 'to some extent killed the culture' and 'rooted Kazakh language out' (Vladimir, 29, Karaganda), making 'Russian the only real language in the country' (Maxim, 24, Almaty). Yet, on the other hand, the Soviets are credited with constructing virtually all the products of modernity visible in the country today, from roads and railways, to schools and hospitals, as well as towns and villages. In other words, 'before no such country as Kazakhstan existed, Kazakhs were a nomadic people and didn't build things (...) most of what is here today is thanks to Russia' (Vladimir, 29, Karaganda). Perhaps the most succinct version of this narrative was: 'without us Kazakhs would still be living in yurts as nomads' (Lev, 24, Almaty). This resonates strongly with Laszczkowski's findings in Astana (2016, p.90), which revealed narratives on building 'civilization' on the empty Kazakh steppe that depend on a dichotomy between rural backwardness versus urban progress and modernity.

Several respondents expressed their own annoyance at the lack of recognition and gratefulness among many Kazakhs for the positive role of Russians and Russian-speakers in the country's development. Rather than reproducing any critiques of Stalinist predations, such acts were things that 'just happened'. The Soviet period was generally presented as non-problematic. Many tended towards idealised and romanticized images of the late Soviet period based on nostalgic visions of a bygone age of unity and peace in the community, 'when neighbourhoods and villages got on well (...) people worked alongside each other (...) the courtyard was like a kindergarten and everyone knew each other, adults and children' (Maxim, 24, Almaty). This was a time when people 'were all pretty equal', 'did not feel superiority from being Russian' and nobody 'got preferential treatment at work' and 'all the nationalities mixed together' (Alexandra, 25, Almaty). 
There was a consistent rejection among participants of any sense of 'colonial guilt', even though most of them were familiar with 'alternative interpretations' that view the Russians as colonial exploiters and occupiers. Many dismissed these accusations on the grounds that 'it is generally uneducated people' (Mikhail, 23, Almaty) and 'those from outside of the cities' (Sergei, 21, Almaty) that hold these 'anti-Russian' views. The consistent views of history displayed among respondents suggest a fairly coherent pro-Russian narrative dominates that dismisses the alternative story of Kazakh victimhood at the hands of Russian and Soviet rule. It appears Russian-speaking minorities imagine their historical role in terms of providing tuition to the ethnic Kazakhs living as nomads, a relationship that has, over two centuries, evolved into a partnership. It is only through the collaboration of Kazakh and the Russian-speaking arrivals, and the subsequent 'mixing of various national groups in large quantities', that Kazakhstan modernised and became a 'fully-fledged country' (Alexander, 25, Karaganda). This way of thinking reproduces a significant amount of the 'cultural colonialism' of the Soviet period, especially at the intersection of the 'cultured' Russian-speakers, 'modernity, civilization and progress' and 'backward' Kazakh-speakers.

Cultural colonialism is also revealed in attitudes toward Kazakh language, a phenomenon David Laitin (1998, p 155) identified as the 'absurdity of assimilation' amongst Russian-speakers in Kazakhstan: the assumption that it is somewhat ridiculous to try and learn Kazakh language when it is 'under-developed' and of little utility. My respondents also took up these positions, pushing back against the promotion of Kazakh language on the grounds that, 'there is no motivation to learn a language you can't use except with some countryside people' (Marina, 22, Almaty). This is contrasted to usefulness of 'European' languages 'spoken by many people across the world'. Encouraging students to learn Kazakh and minimizing the use of Russian would only lead to 'a serious drop in standards, to be blunt, degradation, both cultural and in education levels (Sergei, 21, Almaty). This sense of degradation was presented as a reversal of the progress made by Russian-speaking civilization and culture in the country. In addition, respondents pointed to the senselessness of promoting the state language when 'we already have a perfectly good and modern language of communication - 'Russian' and that 'for all of modern Kazakhstan's history (...) Russians and Kazakhs have lived with this language (...) so why change it?' (Lev, 24, Almaty).

In other words, Russian has always been 'the unifying language in Kazakhstan (...) Russians came and taught Kazakhs, raised their development level. Even today, those who are Kazakh-speaking resort to Russian words' (Ivana 20 Karaganda). Thus, there was scepticism and incredulity at the suggestion the state should prioritize serious resources to the rapid expansion and growth of Kazakh language. These discussions on history and language suggest the younger generation has retained some of the images and discourses central to Soviet-Russian identity. Despite the post-empire, post-colonial setting, the Soviet-Russian way of interpreting history remains, depicting the 
Russians as the benevolent (if at times harsh) elder brother. In leading a family of diverse nations on a pathway of modernity and progress, narrow and petty 'nationalism' is eschewed and issues of unequal power relations, as well as the question of Kazakh victimhood or cultural colonialism, are ignored or concealed. What looms large instead is the vision of Russian-speakers as harbingers of modernity and labourers for progress.

Political Stances toward the State: Reproduction of Discourses on Kazakhstan as a Modernising, Multi-ethnic State

Stances toward the Kazakhstani state were largely de-politicised and tended to involve basic approval of the state's performance. The consistency of these narratives suggests there is a certain hegemonic discourse on the Nazarbayev system as a 'normal', 'peaceful' and 'the best that can be hoped for' in the period when the research was conducted. This is perhaps to be expected; respondents have all gone through decades of socialisation under 'soft' authoritarianism where and the media is controlled and political activism is proscribed by the state. Two main discursive frames of the state were commonly reproduced across respondents in both cities. The first focused on successful development, modernization and state consolidation as a source of pride as a citizen of Kazakhstan. Respondents were all part of a younger generation who have come of age in a phase of good economic growth and decent opportunities, especially in comparison to neighbours in the Post-Soviet space: 'I can say Kazakhstan is better than most CIS states (...) definitely better than Georgia or Ukraine (...) One of the best, or second only to Russia in living standards. Of course, this isn't really about our cultural standards, more our material things' (Vladimir, 29, Karaganda). The country's political stability and the absence of serious internal conflicts was also a source of pride, especially in contrast to the disorder and conflict of neighbouring countries, such as Kyrgyzstan or Russia. $^{24}$ This phenomenon was also recognised by Anna Matveeva (2009: 1118) who noted that 'regional comparisons' shore up legitimacy by delivering what people expect: 'security, growth and welfare'.

The second narrative that was positive to the state concerned Kazakhstan as a 'multi-ethnic' or 'multinational' country (mnogonatsional'naya strana). ${ }^{25}$ Here satisfaction with the relative security and calm in interethnic relations ties in with the Soviet 'Friendship of Nations' imagery of a harmonic and peaceful multinational community: 'I am proud to live in a multicultural nation, I can speak to any ethnic group (natsia) here, I have lots of friends of many national groups, the state system here lets us live in peace' (Ksenia, 22, Almaty). The role of the President is that of the ultimate guarantor of interethnic peace. The absence of 'national tensions' is attributed to the President's ability

\footnotetext{
${ }^{24}$ The Second Kyrgyz revolution of 2010 witnessed ethnic violence between Kyrgyz and Uzbeks communities, while from the winter of 2011 a wave of anti-government protests unfolded in Russia

${ }^{25}$ Perhaps this phrase is best translated as 'a country of many nations', but the definition of nation (natsiya) often takes on its traditional Soviet meaning; natsiya refers to an ethnic group rather than the civic or political nation.
} 
to 'quieten all of this down', allowing 'all the national groups live together easily' in a 'peaceful' manner, without any 'interethnic conflict'. Things are still as they were in the Soviet period, and children study together without being divided into 'Russian' or 'Kazakh' (Ivana, 20, Karaganda).

This generally positive view of the top level of the state (the President and his 'team') and the current status quo should not be interpreted as a deep-rooted Kazakhstani civic identity. Respondents shared a disinterest in politics and had no experience of participation in a civic political community. There was a clear lack of emotional engagement: I found no examples of elaborate narratives or emotionally charged speech in attachment to the state leadership. Instead, respondents offered pragmatic and limited articulations, mostly along lines of 'it is fine', 'things are normal', 'I have no complaints' or 'they do a decent job'. As Natalie Koch (2013: A2) pointed out, this is a 'don't rock the boat mentality' and suggests that many do not feel their personal lives, personal and economic, are particularly linked to the state's activities. When, during interviews, the conversation turned to episodes from everyday life and how things work in the country, a very different reality was reported that sat uneasily with general loyalty to the regime and reproduction of the 'friendship of nations' harmony discourse.

\section{Representations of Ethnic Kazakh Dominance of State Posts}

One key element of this reality was the perceived effects of family ties, nepotism and corruption in the Kazakhstani state. Almost all respondents in this research viewed the state sector as dominated by ethnic Kazakhs who have gained office through kinship and clan ties. Here the discourse of equal citizenship, which respondents embrace, is challenged by the everyday practice and lived experience of respondents in both cities. This includes the virtual impossibility of competing for state jobs on equal grounds with ethnic Kazakhs: 'I'm not sure, if you look at those in the government, well a Russian will never even get into local government of Almaty. That is probably because some people would complain that “this is Kazakhstan and we don't want a Russian in that job"” (Sergei, 21, Almaty). In explaining the commonly known Kazakh monopoly of state sector, there was a split: one part of respondents saw it as evidence of a certain contradiction, in as far as 'all the state jobs go to Kazakhs (...) but Russians are also citizens of Kazakhstan and I suppose they are being oppressed' (Ivana, 20, Karaganda). In contrast, other respondents saw the process as fair and natural: 'In Chechnya the Chechens are the bosses. In Uzbekistan it's the Uzbeks. So here the Kazakhs run the show, it's normal, everyone gets their own state' (Julia, 27, Almaty). This reproduces the primordial component of Soviet nationalities policy, whereby the Eurasian space is carved up into ethno-republics, each containing a titular nation with special rights to the land. 
The above discursive fracture on the role of ethnic Kazakhs reflects a paradox within Russian-speaking Kazakhstani identity: support for the President and his management of interethnic relations sits alongside awareness of ethnic Kazakh domination of state posts and violation of the principle of equality between groups. In other words, respondents want to believe the notion 'all Kazakhstanis are equal and none have privileges' but are confronted with abuse of this by some ethnic Kazakhs, something that, furthermore, is apparently going unpunished. One of the main ways this paradox is overcome is by claiming that it is 'Kazakh' traditions and cultural norms that impede state functioning and economic performance. This provides a non-political explanation that does not blame the President nor view the state as 'nationalising'. Instead, certain ethnic Kazakhs have advantages because 'they have lots of relatives and connections with them, so they try and promote them or hire them at work'. Such practices were alien to 'Russians' and something far less common in Russia itself while, in contrast, 'in Kazakhstan, on the contrary, (these problems) just grow and grow... so, as a result, the average person without special ties has pretty limited opportunities' (Sergei 21, Almaty). Thus, the higher echelons of the state do not promote nepotism, it has its own momentum from below, where 'advantages' are traded along 'family' rather than 'ethnic' lines.

This ties in with a longer tradition of viewing 'Kazakh culture' as inherently backward and clannish, something that can be understood with reference to Soviet-era practices when ethnic Kazakhs used kinship ties in the administrative structures of the Kazakh SSR:

There are not really privileges for them, except that, as the whole government and administration are Kazakhs, they tend to promote 'their' Kazakhs into jobs (...) But that is not a special plan (...) After all, they hire Kazakhs who don't speak Kazakh (...) family ties are dominant, that is the Kazakh tradition, even in the Soviet period these things went on in the communist party (Alessia, 18, Almaty)

Many respondents elaborated at some length on how Kazakhs employed patriarchal structures and nepotistic favour trading in the workplace. This aspect of Kazakh working culture was highlighted as a good reason not to work for domestic Kazakhstani companies, where things 'are definitely not arranged according to ability' and 'relatives work together to get themselves into the top positions', following the principle 'if one person gets ahead he must promote his own people' (Ruslan, 22, Karaganda). This way of interpreting the problem presents it as something harming all citizens outside of these clan networks, such as when 'government programmes, which are supposed to help poorer families and small business, are killed off by officials who give this stuff to their relatives' (Vladimir, 29, Karaganda). 
It is worth underlining that ethnic Kazakh domination of state posts was not generally perceived through an ethnic lens of 'them' (ethnic Kazakhs) versus 'us' (non-Kazakhs). Instead it was framed in terms of corruption, a problem that adversely affects all citizens of Kazakhstan including many ethnic Kazakhs, who do not enjoy such connections (svyazi). It is important, however, to note the majority of respondents did not view corruption and nepotism as a vital and current impediment to their immediate socioeconomic prospects. It would appear many the observations made by Michele Commercio (2010) still hold true: Russian-speakers in Kazakhstan, despite lacking their own powerful informal networks, have managed to compensate for this with success in the private sector of a growing economy. Thus, increasing acceptance of ethnic Kazakh domination over state sector jobs has not led to resentment and emigration but a stabilization of out-migration alongside the emergence of a middle-class.

\section{De-politicised Stances and Disinterest in Special Political Representation}

In conversations about the state and the role of the titular nation, one clear theme was the prevalence of a certain depoliticised consciousness. No respondents were able to elaborate on the purpose of state bodies such as the ANK (The Assembly of the People of Kazakhstan), and no respondent was aware of any organisation that worked in favour of the 'Russians' or 'Russian-speakers' of Kazakhstan. Indeed, the dominant view was that it is somehow pointless to be politically active, to self-organise and to lobby the state. Respondents argued that 'dissatisfied' citizens should not vent their displeasure or dissatisfaction by overt political activity. Instead, voting with one's feet was offered as the most appropriate solution: 'If Kazakhstan is the motherland for Kazakhs then there shouldn't be any Russian societies or organisations. It might be fine if there were large-scale problems of oppression of Russians then yes... but if they are oppressing here, then we can just leave' (Sveta, 21, Karaganda). The preference for disengagement and non-involvement in politics shows continuity with Soviet political culture in the Kazakh SSR where there was relatively little dissent or oppositional activity. ${ }^{26}$ The post-1995 termination of democratization in Kazakhstan and exclusion of oppositional groups from political participation appears only to have reinforced the political habits typical of Soviet-Russian identity. Attitudes to 'normal' political behaviour among respondents revolved around themes of 'the less you know the better' and 'don't stick your head in a noose': The political system was presented as a thing not 'of the people' but a separate world:

Even if you did manage to get set up there, you still could not change anything. You would get sucked into the various flows up there. Once someone is in a system like that he can't hold on to his own (political) positions. Either he gets into the system and becomes part of it or he will be ejected from it (Alexander, 25, Karaganda).

${ }^{26}$ Political activation in Kazakhstan, unlike the Baltic States, was curtailed after the December 1986 Jeltoqsan events. Furthermore, independence did not come from mass mobilization of a popular front movement demanding free elections and an end to KPSU rule. Kazakhstan was, in fact, the last of the Soviet republics to declare its independence in 1991. 
The idea of non-systemic opposition was viewed as even more pointless, and only likely to be counter-productive, creating even more problems: I don't think that going on the streets will lead to anything good. The majority of this country is Kazakh (...) this would just enflame things; there would be more conflict. It's better not to get involved in this kind of thing' (Sergei, Almaty 21).

These sentiments tie in well with the analysis of Dave (2007), who predicted that exclusion from politics would breed apathy and disengagement among Russian-speakers. Deprived of both participatory democracy and those who could articulate their concerns, Russian-speaking minorities leave high politics to the 'big fishes' and do not contest the basic premises of state propaganda. In imagining the political system, they envision two main options. One is to crawl up the greasy pole, build a career in politics, make connections and get ahead (i.e. personal enrichment). The other is to forget about politics, delegate all responsibility to the President/authoritarian state and forget about trying to change or influence things. In case of complications or a worsening in the political, social or economic situation, the solution is not to band together to enact change but to leave the country. If we recall that Russian-speaking Soviet citizens were often able to move to different regions to improve their lot, it would appear the above way of viewing politics does not constitute a break from the Soviet-Russian habitus. Perhaps one factor that makes these depoliticised stances stable is the continuing coherence and strength of a Russian cultural-linguistic space, a factor explored below in the final section of the paper.

\section{Confidence in Russian Linguistic and Cultural Spaces: A Delicate Equilibrium?}

Despite the fact that ethnic Kazakhs have enjoyed a demographic majority since 1999, respondents did not readily identify as a 'national minority'. This status was often rejected on the grounds of belonging to the Russian linguistic and cultural sphere. Here we find society imagined as bipolar, with a stable equilibrium between Russian and Kazakh speaking components, which are the two central components of the country, while all the rest are malie $\operatorname{narodi}^{27}$ (small nations):

I don't know these organisations and I don't see the point as lots of us live here and I don 't feel worried. I think it is 50-50 between Russian and Kazakh speaking here. I don't feel deprived of rights at this moment and I don't feel the need to defend my culture like those malie narodi do, such as Chechens or Georgians. (Vladimir, 29, Karaganda)

27 malie narodi, is a term of Soviet origin used to describe small, compactly settled ethnic minorities within titular republics or autonomous zones. 
Organisations such as the ANK peddle an officially approved ethno-cultural identity to non-titular citizens of Kazakhstan, encouraging the activation of ethnic-based identities. Yet, over the many decades of the USSR, the Russian-speaking populations of the non-Russian republics were Sovietised to a high degree and tended to prefer the broader category of 'Soviet' or 'Russian' to narrower ethnic identities (Arutyunyan, Drobizheva 1987; Kaiser 1994). Thus, there is continuity in younger Russian-speakers today who reject ethnic identity as a principle of state organisation: 'Anyone can represent us; let it be a Kazakh, a Russian or a Jew. There is no difference. The only thing is they should defend interests of the country. I don't think there are really big differences between Kazakhs and Russians. They want the same things in life' (Lev, 25, Almaty).

Thus, the sense of belonging to a large and cohesive Russophone core was central to rejecting the notion of 'belonging to a minority', in other words, 'while the vast majority speak Russian, I won't feel part of a minority' (Alexander, 25, Karaganda). While Karaganda and Almaty were presented as secure Russian cultural and linguistic spaces where Russian remains the lingua franca for business and education, this was not seen to be the case in the countryside and the South and West of the country (Ksenia, 22, Almaty). Yet, respondents were not particularly alarmed about the prospects for Russian language and culture in Almaty and Karaganda, especially given that many did not think efforts to promote Kazakh as the state language were actually having much effect. However, it must be underlined that demographic shifts and internal migration may straining this equilibrium; the continuing inflow of rural Kazakh-speakers into urban areas and a corresponding growth of Kazakh as the language of instruction in nurseries, schools and universities, would surely change the balance in urban spaces.

Yet, my respondents identified a rather different issue as the key threat to the current equilibrium: what will happen after Nazarbayev, a figure seen to be central in holding together the Kazakh-speaking and Russian-speaking parts of the country, leaves office. The central theme here was 'someone will take his place intent on stirring up trouble amongst the national groups' (Maxim, 24, Almaty):

Nazarbayev holds the balance... it's pretty scary to think about what will happen when he leaves the scene. There are many parties who are trying to make Kazakhstan for Kazakh people only. (...) even though they are still weak at this point. But if they become stronger... as there are thirteen million people in Kazakhstan and only five big cities. So people from rural areas may account for the majority and suddenly start something. (Oleg, 25, Almaty)

The fear of rural Kazakhstan is linked with the spectre of Kazakh nationalism, which is in turn connected to concerns about demographic change. Thus, there is the anxiety that 'some young guy will come after Nazarbayev 
and literally start a revolution, particularly in the area of language, education. Then there will be some kind of collapse here' (Sveta, 21, Karaganda). The fear of rural Kazakhstan and Kazakh nationalism should be interpreted in the context of the wider way respondents imagined Kazakhstani society and inter-group relations. A vital part of this is the separation of ethnic Kazakhs into two groups: Russian-speaking 'friendly' more 'educated', 'cultured' and 'normal' Kazakhs and 'less friendly' Kazakh-speaking Kazakhs of rural origins. As mentioned above in the section on historical memory, the friendship between 'cultured' Kazakhs and Russians is imagined to be traceable back through the centuries of sharing a homeland.

We have lived together for a long time and have the same land, everything in common... we lived and live in harmony.. we know we will always be together. Maybe less educated Kazakhs might be more hostile to Russians.. but I have only spoken to those more educated (...) they are more tolerant and they don't have any of this nationalism (...) (Maxim, 24, Almaty)

In this data sample, respondents from Almaty commented far more on rural Kazakhs entering their city than those from Karaganda. Here these arrivals, 'who have only seen horses and fields all their lives', are ignorant of the 'socalled civilized world' and tend to think 'Kazakhstan is for Kazakhs' and behave inappropriately by 'shouting in the street' (Maxim, 24, Almaty). 'Kazakhs from auls and kolkhozes or southern regions' coming to the cities are perceived to be prejudiced towards other nationalities, resulting in racially motivated assaults (Vladimir 29 Karaganda). This common-sense view explains the perceived susceptibility of rural Kazakhs to anti-Russian prejudice or 'nationalism' by reference to their 'lower education levels' and feelings of inferiority:

They come and see Almaty (...) They look at this big town and see Russians who have achieved this or that or have this job or just make more money than them and think it is unfair. But I think this is incorrect. No matter who you are, Russian or whatever, there are lots of nationalities... whoever gets ahead and achieves things, it depends on them. (Sergei, 21, Almaty)

Laszczkowski (2016: 59) also encountered this sentiment toward so-called mambeti in his Astana interviews, who were presented as ignorant, country people that are embittered by the socio-economic contrasts they see on TV. Arriving in cities, they are seen to be unable to adapt to city life and prone to outbreaks of aggression. ${ }^{28}$ This discourse on rural Kazakhs appears to have formed from everyday contact in Almaty. One respondent claimed

\footnotetext{
${ }^{28}$ The word Mambet, taken from the name Muhammad, is a pejorative term with Soviet-era roots used by Russian-speakers to describe rural Kazkakhs arriving in the cities.
} 
'Karaganda is a more Russian place (...) if you go south you will feel like a minority (...) the closeness of Russia gives me the feeling this city is fully Russian culturally' (Ivana 20 Karaganda). It may be that narratives on rural Kazakhs are more specific to Almaty and Astana than Karaganda and East Kazakhstan.

For Almaty respondents, it seems criticizing the behaviour of the rural Kazakhs is a way of reaffirming their values: egalitarianism, internationalism and behaving like a 'cultured' person. Articulating these principles expresses solidarity with the 'civilized majority'. As one respondent put it: 'We' who are 'born here and speak Russian' also 'see ourselves as more cultured' than those from the countryside. Due to their 'lack of manners and culture (...) we sometimes subconsciously start to associate Kazakh language with bad behaviour and poor manners' (Alessia, 18, Almaty). This manner of defining in-group membership highlights the socio-cultural (language, manners, culture) rather than ethnic factors behind group identity difference and highlights how Almaty Russian-speakers gain security and confidence through 'alliance' with Russified Kazakhs. It also fits with research on Post-Soviet Bishkek that reveals how the 'ruralisation' of urban spaces causes a reaction from 'native urbanites' who hold similar positions regardless of ethnicity (Flynn and Kosmarskaya 2012). Laszczkowski (2016, p.70) also found that 'young "urban" Kazakhs and Russians tended to group together, pointing to the "rural" as their common "spatial other". Imaginaries of Russian-speaking Kazakhs as 'on the same side' against 'uncivilized' rural arrivals offer another manifestation of how Soviet-Russian identity has evolved in a post-Soviet context. The perceived warmth of Russian-speaking Kazakhs towards Russian-speaking minorities reassures urban Russian-speaking minorities about their place in the country. The fear this balance will be destroyed is a factor in the future security of the Russophone community in Kazakhstan. On the other hand, there would appear to be considerable potential for Russian-speaking minorities to merge with Russian-speaking Kazakhs into the category of 'cultured' (which could be code for 'Russian -speaking') Kazakhstani citizen. The positionality of Russian-speaking Kazakhs between Russianspeaking minorities and Kazakh-speaking Kazakhs is clearly of upmost importance and one that future research should address.

\section{Conclusion}

In examining some of the key discourses among Russian-speaking minorities towards the end of Nazarbayev's period of rule, this paper has highlighted some important ways in which Russian-speaking minorities are negotiating the transition from a Soviet-Russian to post-Soviet identity. This paper has offered the argument that Soviet-Russian identity has not lost its salience with the collapse of the USSR and that the 'cultural colonial' habitus of the Soviet period has survived in a new post-Soviet generation. In some ways this is paradoxical: this younger generation has, 
after all, no lived experience of the Soviet system. Nonetheless, there is continuity with how the past is imagined, as well as the sense of alliance between 'progressive' Kazakhs and 'civilizing' Russians. Kazakhstan in its modern form is understood to be a result of mutual labour of Kazakhs and Russians. This imagined alliance breeds confidence in the security and cohesion of Russian linguistic and culture zones and helps ensure that Russianspeaking minorities remain de-politicised and take largely 'loyal' stances toward the Kazakhstani state.

Such visions are untroubled by accusations of colonialism, occupation and repression. Cultural colonialism also relates to attitudes to Kazakh language. Despite decades of rhetoric on the need for its implementation as a state language, respondents still tended to reproduce a sense of incredulity that state resources would be spent to replace Russian with Kazakh as the language of interethnic communication. It appears 'cultural colonialism' is also at work in attitudes to the 'cultural difference' of rural Kazakhs, who appear to play the role of 'Other' for Russian-speaking group identity. In a way, the language of '(un)educated' and '(un)civilized' groups seem to be part of generational continuity for the 'children of empire'. As was the case with their parents, they tend to perceive of themselves as the 'higher part' of a social and cultural order. Crucially, in this divide Russian-speaking Kazakhs are on the same side as Russian-speaking minorities.

On the other hand, this paper has also revealed some of the complexity behind attitudes and stances toward the state. Positive attitudes to the upper echelons of the state and the President are based on the state's 'performance' in key areas, such as economic growth, political stability and interethnic peace. The 'modernising nationalism' of the state is responded to in positive terms, and, importantly, respondents did not view the Kazakhstani state in ideological terms as 'nationalising'. Instead, the ethnic Kazakh monopoly on political life and state jobs is seen to be the unfortunate result of nepotism and corruption rather than the intended result of state policy. Such a view may be understood as a rationalisation of a depoliticised consciousness. Rather than interpreting problems as the fault of the government and taking a political stance demanding 'something must be done', such risks are avoided by shifting the focus to deeper cultural causes (Kazakh kinship ties) about which 'nothing can be done'. Thus, the central authorities are let off the hook as such practices are embedded deep in Kazakh culture. Risking one's own welfare to advance a political agenda 'from below' is viewed with great scepticism; it is far more 'normal' to avoid political positions and deny any agency for the individual or the community in politics, which is delegated to a powerful elite. This brings us to the fundamental argument of the paper: continuities with Soviet political stances are clear but this is reinforced by the post-ideological, soft authoritarian, consumer-driven environment of the post-Soviet context. 


\section{Bibliography}

Akiner, S (2005) 'Towards a Typology of Diasporas in Kazakhstan'. In: T. Atabaki, S. Mehendale (eds) Central Asia and the Caucasus: Transnationalism and Diaspora. London and New York: Routledge, 21-65.

Arutyunyan, Y.U and Drobizheva, L.M (1987). Mnogobrazie Kulturnoi Zhizni Narodov SSSR, [The diversity of the cultural life of the peoples of the USSR]. Izdatelstvo 'Misl', Moscow.

Astana, (2009) Population Census of the Republic of Kazakhstan 2009, condensed results, under the editor A. A. Smailova. Available at stat.gov.kz/getImg?id=WC16200032648. Last Accessed 3.3.2019.

Astana Times (2017) Kazakhstan to Switch to Latin Alphabet by 2025. Available at https://astanatimes.com/2017/10/kazakhstan-to-switchto-latin-alphabet-by-2025/. Accessed 11/4/19.

Barrington, L., Herron, E., Silver, B. (2003) 'The Motherland is Calling. Views of Homeland among Russians in the Near Abroad', World Politics, 55(2): 290-313.

Bourdieu, P (1990) The Logic of Practice. Stanford, CA: Stanford University Press.

Brubaker, R (1994) 'Nationhood and the National Question in the Soviet Union and Post-Soviet Eurasia: An Institutionalist Account', Theory and Society, 20 (1): 47-78.

Brubaker, R (1995) 'National Minorities, Nationalizing States, and External National Homelands in the New Europe', Daedalus, 124 (2): $107-132$.

Brubaker, R (2004) Ethnicity without Groups. Harvard University Press.

Brubaker, R (2011) 'Nationalizing States Revisited: Projects and Processes of Nationalization in Post-Soviet States', Ethnic and Racial Studies, 34(11): 1785-1814.

Chari, S., Verdery, K (2009) 'Thinking between the Posts: Postcolonialism, Postsocialism, and Ethnography after the Cold War'. Comparative Studies in Society and History, 51 (1): 6-34.

Cheskin A (2013) 'Exploring Russian-Speaking Identity from Below: The Case of Latvia', Journal of Baltic Studies, 44:3

Cohen, R (2008), Global Diasporas, London, Routledge.

Commercio, M (2010) Russian Minority Politics in Post-Soviet Latvia and Kyrgyzstan: The Transformative Power of Informal Institutions. Philadelphia, PA: University of Pennsylvania Press.

Cummings, S (2005) Kazakhstan: Power and the Elite. London and New York: I.B.Tauris.

Dave, B (2004) Management of Ethnic Relations in Kazakhstan: Stability without Success. In: Slater, W. and Wilson, A., (eds.), The Legacy of the Soviet Union. Palgrave Macmillan, pp. 83-100.

Dave, B (2007) Kazakhstan: Ethnicity, Language and Power. London and New York, Routledge.

Diener, A. (2002) 'National Territory and the Reconstruction of History in Kazakhstan', Eurasian Geography and Economics 43 (7): $565-$ 83.

Ekiert, G. (2015) 'Three Generations of Research on Post Communist Politics-A Sketch', East European Politics \& Societies and Cultures, 29 (2): 323-337.

Eurasianet.org (2014) 'Kazakhstan's Nazarbayev Moots Dumping the "Stan”, February 7, 2014, http://www.eurasianet.org/node/68017 (last accessed 30/7/16)

Flynn, M. and Kosmarskaya, N (2012) 'Exploring "North" and "South” in Post-Soviet Bishkek: Discourses and Perceptions of Rural-urban Migration’, Nationalities Papers, 40(3): 453-471.

Hosking, G.A (2006) Rulers and Victims: The Russians in the Soviet Union (Harvard University Press)

Isaacs, R., Polese, A (2015) 'Between "Imagined" and "Real” Nationbuilding: Identities and Nationhood in post-Soviet Central Asia', Nationalities Papers, 43(3): 371-382. 
Kaiser, R. J (1994) The Geography of Nationalism in Russia and the USSR, Princeton University Press

Karavan (2016), 11 May 2016. Russkiy iskhod. Stanet li Kazakhstan monoetnicheskim gosudarstvom? (The Russian exodus. Will Kazakhstan become a monoethnic state?) available via https://www.caravan.kz/news/russkijj-iskhod-stanet-li-kazakhstanmonoehtnicheskim-gosudarstvom-366085/ accessed May 2017

Kesküla, E (2018). 'Miners and Their Children: The Remaking of the Soviet Working Class in Kazakhstan'. In: C. Hann, J. Parry (eds), Industrial Labor on the Margins of Capitalism. Precarity, Class and the Neoliberal Subject. London and New York: Berghahn

King, C. and Melvin, N (2000) 'Diaspora Politics. Ethnic Linkages, Foreign Policy and Security in Eurasia', International Security, Vol. $24: 3$

Koch, N (2013) 'Technologizing Complacency: Spectacle, Structural Violence, and 'Living Normally' in a Resource-rich State'. Political Geography 37: A1-A2.

Kolstø, P (1998) 'Anticipating Demographic Superiority: Kazakh Thinking on Integration and Nation Building'. Europe-Asia Studies, 50(1), 51-69

Kolstø, P (ed) (1999) Nation-building and Ethnic Integration in Post-Soviet Societies. Westview Press.

Kosmarskaya, N (2006), 'The Children of the Empire' in Post-Soviet Central Asia (Natalis Press, Moscow).

Kosmarskaya, N (2011) 'Russia and Post-Soviet “Russian Diaspora”: Contrasting Visions, Conflicting Projects', Nationalism and Ethnic Politics, 17 (1): 54-74.

Kosmarskaya, N. (2014) 'Russians in Post-Soviet Central Asia: More 'Cold' than the Others?' Journal of Multilingual and Multicultural Development, 35: 9-26.

Kotkin, S. and Beissinger, M. R (2014) “The Historical Legacies of Communism: An Empirical Agenda,” in Beissinger, M. and Kotkin, S. (eds) Historical Legacies of Communism in Russia and Eastern Europe. Cambridge: Cambridge University Press, pp. 1-27.

Kudaibergenova, D (2015) The Ideology of Development and Legitimation: Beyond 'Kazakhstan 2030', Central Asian Survey, 34:4, 440455

Laitin, D (1998) Identity in Formation: the Russian-speaking Populations in the Near Abroad (Ithaca: Cornell University Press).

Laruelle, M (2015) "The Three Discursive Paradigms of State Identity in Kazakhstan: Kazakhness, Kazakhstanness, and Transnationalism.” In M. Y. Omelchieva (ed), Nationalism and Identity Construction in Central Asia: Dimensions, Dynamics, and Directions, Lanham, MD: Lexington Books, pp.1-20.

Laruelle, M (2016): Why No Kazakh Novorossiya? Kazakhstan's Russian Minority in a Post-Crimea World, Problems of PostCommunism, Published online: 24 Oct 2016.

Laszczkowski, M (2016) City of the Future: Built Space, Modernity and Urban Change in Astana, Berghahn Books, New York.

Levada, Y. A. (ed) (1993) Sovetskii Prostoi Chelovek. Izdatelstvo Intercentr.

Melvin, N. (1998) 'The Russians: Diaspora and the End of Empire', in: King, C. and Melvin, N. (eds.), Nations Abroad. Diaspora Politics and International Relations in the Former Soviet Union (Westview Press), pp.27-58.

Millar, J.R. (1985) The Little Deal: Brezhnev’s Contribution to Acquisitive Socialism, Slavic Review, 44 (4): 694-706.

Morrison, A. (2016) Russia's Colonial Allergy. Eurasianet. Available at: eurasianet.org/russias-colonial-allergy. Last accesed 20-10-18.

Nazarbayev, N (2012) 'Kazakhstan 2050: The New Political Course of the Established State' available at: http://www.akorda.kz/ru/events/astana kazakhstan/participation in events/poslanie-prezidenta-respubliki-kazahstan-lideranacii-nursultana-nazarbaeva-narodu-kazahstana-strategiya-kazahstan-2050-novyi-politicheskii- last accessed 3/3/19.

Nazarbayev, N. (2019) Obrashcheniye Glavy gosudarstva Nursultana Nazarbayeva k narodu Kazakhstana [Address of the Head of State Nursultan Nazarbayev to the People of Kazakhstan]. Available at: http://www.akorda.kz/ru/speeches/internal political affairs/in speeches and addresses/obrashchenie-glavy-gosudarstvanursultana-nazarbaeva-k-narodu-kazahstana. Accessed 11/4/19.

Oko, N (2007), Managing Ethnicity under Authoritarian Rule: Transborder Nationalisms in Post-Soviet Kazakhstan, Institute of Developing Economies, JETRO Chiba, Japan, available at http://www.ide.go.jp/English/Publish/Download/Report/2006/2006_04_31.html (last accessed 30/7/16) 
O’Beachain, D. and Kevlihan, R. (2013), Threading a Needle: Kazakhstan between Civic and Ethno-nationalist State-building, Nations and Nationalism 19 (2).

Peyrouse, S. (2007) 'Nationhood and the Minority Question in Central Asia: The Russians in Kazakhstan', Europe-Asia Studies, 59.3.

Peyrouse, S. (2008a), 'The Russian Minority in Central Asia: Migration, Politics, and Language', The Woodrow Wilson International Centre for Scholars, Occasional paper no. 297.

Peyrouse, S. (2008b) The "Imperial Minority": An Interpretative Framework of the Russians in Kazakhstan in the 1990s, Nationalities Papers, 36:1, 105-123.

Rees, K. M., Webb Williams, N. (2017) Explaining Kazakhstani Identity: Supraethnic Identity, Ethnicity, language, and Citizenship, Nationalities Papers, 45:5,815-839.

Schatz, E. (2000) The Politics of Multiple Identities: Lineage and Ethnicity in Kazakhstan, Europe-Asia Studies, 52(3): 489-506.

Schatz, E. (2012) Modern Clan Politics : The Power of Blood in Kazakhstan and Beyond, University of Washington Press, Seattle.

Smith, G. (1999) The Post-Soviet States: Mapping the Politics of Transition (London, Arnold).

Smagulova, J. (2008) Language Policies of Kazakhization and Their Influence on Language Attitudes and Use, International Journal of Bilingual Education and Bilingualism, 11(3-4): 440-475.

Smagulova, J. (2016), The Re-Acquisition of Kazakh in Kazakhstan: Achievements and Challenges, In: J. Ahn, J. Smagulova (eds) Language Change in Central Asia, De Gruyter, Berlin, Boston, pp.89-108.

Stasiulis, D and Yuval-Davis, N. (1995), Introduction: Beyond Dichotimies - Gender, Race, Ethnicity and Class in Settler Societies', In: 'Unsettling Settler Societies, Articulations of Gender, Race, Ethnicity and Class', SAGE Series on Race and Ethnic Relations, Volume 11, pp.1-38.

Suny, R. G. (2012) The Contradictions of Identity: Being Soviet and National in the USSR and after. In: M. Bassin and C. Kelly (eds) Soviet and Post-Soviet Identities. Cambridge University Press, pp.23-66.

Tengri News (2013) Nazarbayev calls Kazakhstan to Learn English. Available at: https://en.tengrinews.kz/edu/Nazarbayev-callsKazakhstan-to-learn-English-24393/. Accessed 11/4/19.

Tocqueville, A.d. (1805-1859) (1955), The Old Régime and the French Revolution, Dubleday, Garden City, N.Y.

Weber, M. (1864-1920) (2011) The Protestant Ethic and the Spirit of Capitalism, Oxford University Press, New York. 